\title{
Impact of thinning on carbon storage of dead organic matter across larch and oak stands in South Korea
}

\author{
Seongjun Kim ${ }^{(1)}$, \\ Seung Hyun Han ${ }^{(1)}$, \\ Jongyeol Lee ${ }^{(1)}$, \\ Choonsig Kim ${ }^{(2)}$, \\ Sang-Tae Lee ${ }^{(3)}$, \\ Yowhan Son ${ }^{(1-4)}$
}

\begin{abstract}
Dead organic matter is important in carbon $(C)$ sequestration because it accounts for a significant proportion of forest $C$ storage. As thinning could alter the $C$ storage of dead organic matter, this study aimed to assess the effect of thinning on the $\mathrm{C}$ storage of dead organic matter including the forest floor, mineral soil at a depth of $0-30 \mathrm{~cm}$, and coarse woody debris in larch and oak forests in South Korea. Differing intensities of thinning were applied to four larch and four oak stands, and the $C$ storage of dead organic matter in thinned and control plots was compared three years after thinning. The effect sizes were estimated based on Hedges' $d$ to measure the influence of thinning. Total $C$ storage of dead organic matter tended to be higher in the thinned plots (larch: $82.45 \mathrm{Mg} \mathrm{C} \mathrm{ha}^{-1}$ and oak: $82.56 \mathrm{Mg} \mathrm{C} \mathrm{ha}^{-1}$ ) than in the control plots (larch: $72.07 \mathrm{MgC} \mathrm{ha}$ and oak: $74.79 \mathrm{MgC} \mathrm{ha}^{-1}$ ). However, estimation of effect size found that the cumulative effect size was not significant for the $C$ storage of the forest floor, mineral soil, coarse woody debris, and dead organic matter. Only a few of the individual treatments exhibited significant effect sizes for mineral soil $C$ storage in two larch stands and coarse woody debris C storage in two oak stands. The results indicated that the applied thinning treatments might have no consistently significant impact on the $\mathrm{C}$ storage of dead organic matter in the larch and oak stands after three years, though thinning may have had an idiosyncratic influence on the $\mathrm{C}$ storage of dead organic matter in a few of the study stands.
\end{abstract}

Keywords: Carbon Sequestration, Dead Organic Matter, Effect Size, Forest Thinning

\section{Introduction}

Increasing attention has been paid to carbon (C) cycling in ecosystems because of growing concern about the elevated level of atmospheric carbon dioxide (Khaine \& Woo 2015). Since forests act as the principal C storage system in terrestrial ecosystems and are sensitive to anthropogenic activity, appropriate forest management is considered important for $\mathrm{C}$ sequestration (Boerner et al. 2008, Powers et al. 2012). Thinning treatment, which is selective logging to enhance the value of forests, is known to alter the forest $C$ storage by reducing the standing tree density and stimulating growth of the remaining trees (Zhou et al. 2013). In addition, thinning alters the microclimate and organic matter budget, and consequently the forest $\mathrm{C}$ dynamics (Jandl et al. 2007).

Dead organic matter, which originates from living organisms, accounts for approximately half of the forest C storage (Boerner et al. 2008, Powers et al. 2012). Fallen leaves, branches, and coarse woody debris (CWD) are the primary forms of dead organic matter, whose quantity and quality are related to the succession stage and forest management (Powers et al. 2012, Ko et al. 2014). Mineral soil stores a large volume
(1) Department of Environmental Science and Ecological Engineering, Graduate School, Korea University, Seoul 02841 (Korea); (2) Department of Forest Resources, Gyeongnam National University of Science and Technology, Jinju 52725 (Korea); (3) Forest Practice Research Center, National Institute of Forest Science, Pocheon 11186 (Korea); (4) Department of Biological and Environmental Sciences, Qatar University, Doha (Qatar)

@ Yowhan Son (yson@korea.ac.kr)

Received: Jul 23, 2015 - Accepted: Nov 25, 2015

Citation: Kim S, Han SH, Lee J, Kim C, Lee S-T, Son Y (2016). Impact of thinning on carbon storage of dead organic matter across larch and oak stands in South Korea. iForest 9: 593598. - doi: 10.3832/ifor1776-008 [online 2016-03-01]

Communicated by: Ana Rey of organic $C$ derived from the primary forms of dead organic matters. Accordingly, it plays a crucial role in $\mathrm{C}$ sequestration as a large and stable form of $C$ storage in forests (Lal 2005). As the balance and storage of organic matter may be influenced by thinning, understanding the $C$ status of dead organic matter in thinned forests is important in the context of forest $C$ sequestration (Schilling et al. 1999, Kim et al. 2009, 2015a).

Larch (Larix spp.) and oak (Quercus spp.) stands are important deciduous stand types in Korean forestry. Managing larch forests is one of the primary challenges in Korean forestry, because Japanese larch (L. kaempferi) has been widely used for national reforestation programs since 1960 s (Lee et al. 2010, Kim et al. 2015b). Meanwhile, oak stands have also received temperature and the abundance of pine wood nematode, both of which could result from climate change, have been predicted to accelerate the succession of coniferous stands to oak-dominated deciduous stands in Korea (Byun et al. 2013, Kwak et al. 2012). The management of oak stands has, therefore, become another important spective of climate change adaptation.

Effect size (ES) estimation, such as Glass's $\Delta$ and Hedges' $d$, was originally developed growing attentions because increases in air challenge for Korean forestry from the per- 
to standardize the comparison of results from multiple references; thus, it shares a similar concept to statistical methods for multi-site studies (Gurevitch \& Hedges 1999, Nakagawa \& Cuthill 2007). Standardized comparison based on ES estimation could provide insights into the effect of thinning on the $C$ storage of dead organic matter across study sites, because this form of $C$ storage is known to vary with site conditions (Boerner et al. 2008). Therefore, the present study aimed to examine the effect of thinning on the $C$ storage of dead organic matter, including that of the forest floor, mineral soil, and CWD in larch and oak stands in South Korea using ES estimation.

\section{Materials and methods}

\section{Study stands}

The present study was conducted at four larch forests (Gwangneung: GN; Inje: IJ; Muju 1: MF; Muju 2: MS) and at four oak forests (Hamyang: HA; Hoengseong: HS; Sancheong: SC; Yangyang: YG) in South Korea (Tab. 1). The stand size is approximately 6 ha for MS and YG, 5 ha for GN, IJ, and HS, 4 ha for MF and SC, and 3 ha for $\mathrm{HA}$, respectively. Four of the study stands (GN, IJ, HS, and YG) are located in central Korea, while the others are located in southern Korea. All of the study stands are located in the temperate zone with hot humid summers and cold dry winters. The stand ages are 41-60 years for the larch stands and 31-50 years for the oak stands (Tab. 1). Mean diameter at breast height and tree height tend to be higher in the larch stands than in the oak stands (Tab. 1). The altitude and slope of the study stands are $140-930 \mathrm{~m}$ and $18-32^{\circ}$ for the larch stands, and $270-860 \mathrm{~m}$ and $21-31^{\circ}$ for the oak stands (Tab. 1). The dominant soils in the study stands are acidic soils with a sandy loam, loamy sand, or loamy texture. Soil gravimetric water content, $\mathrm{pH}, \mathrm{C} / \mathrm{N}$ ratio, and cation exchange capacity are 13.7-32.3\%, 4.52-5.20, 15.4-32.8, and 10.0-16.9 $\mathrm{cmol}_{\mathrm{c}} \mathrm{kg}^{-1}$ respectively for the larch stands, and $23.0-36.6 \%, 4.27-5.43,10.7-22.5$, and 9.8$13.9 \mathrm{cmol}_{\mathrm{c}} \mathrm{kg}^{-1}$ respectively for the oak stands (Tab. 1).

Each study stand was split into three treatment plots of similar size according to the applied thinning intensity: unthinnedcontrol (control), intermediate thinning (I), and heavy thinning $(\mathrm{H})$. The thinning intensities (based on the removed basal area) ranged from $17 \%$ to $24 \%$ and $15 \%$ to $22 \%$ for the I treatments and from $30 \%$ to $44 \%$ and $30 \%$ to $35 \%$ for the $\mathrm{H}$ treatments in the larch and oak stands, respectively (Tab. 1). The thinning treatments were carried out following the stem-only harvesting method, and thinning residues such as fallen leaves, slashes, and stumps were not removed from the treatment plots. Individual treatment plots were located nearby other treatment plots in the same study stand; thus, the three treatment plots within a study stand shared similar site conditions. Three permanent subplots were established within each treatment plot for sampling and field measurements. The subplots were generally circular with a $10 \mathrm{~m}$ radius $\left(314 \mathrm{~m}^{2}\right)$, but those in the $\mathrm{IJ}$ and $\mathrm{YG}$ sites differed in size at $9 \mathrm{~m}\left(254 \mathrm{~m}^{2}\right)$ and 8 $\mathrm{m}\left(200 \mathrm{~m}^{2}\right)$, respectively.

The thinning treatments were applied to SC and HA in 2007, to HS and YG in 2010, and to GN, IJ, MF, and MS in 2011, and the C storage of dead organic matter was measured for SC and HA in 2010, for HS and YG in 2013, and for GN, IJ, MF, and MS in 2014. Even though these differences in the study period may have influenced the results of the present study in the case of extreme climatic events during the study period, whether the climatic patterns significantly affected the results is uncertain because of the lack of climatic data available for the study stands.

\section{Sampling and laboratory analysis}

Sampling and field measurements were conducted three years after the thinning treatments. The samples for the forest floor and the mineral soil were collected at three random points within the subplot. At each sampling point, the forest floor was sampled with a $900-\mathrm{cm}^{2}$ quadrat, and mineral soil was collected at depths of $0-10,10-$ 20 , and $20-30 \mathrm{~cm}$ using a $10-\mathrm{cm}$-long cylindrical corer (Korea Forest Research Institute 2010). Three forest floor and nine mineral soil samples (three mineral soil samples per depth) were consequently collected from each subplot. The wet mass of CWD ( $>10 \mathrm{~cm}$ in diameter and $>1 \mathrm{~m}$ in length) was measured in a $100 \mathrm{~m}^{2}$ sub-subplot within the subplot, and CWD samples from the sub-subplots (zero to three samples per sub-subplot depending on CWD quantity) were also collected to measure the $C$ concentration and the dry mass to wet mass ratio of CWDs (Korea Forest Research Institute 2010). The total number of samples collected from all of study stands was 216,648 , and 76 for the forest floor, mineral soil, and CWD, respectively.

The forest floor and the CWD samples were dried at $85^{\circ} \mathrm{C}$ prior to measuring the dry mass, and the soil samples were airdried and sieved through a $2 \mathrm{~mm}$ mesh screen. The soil bulk density was calculated

Tab. 1 - Summary of the stand characteristics of the larch (Gwangneung: GN; Inje: IJ; Muju 1: MF; Muju 2: MS) and oak stands (Hamyang: HA; Hoengseong: HS; Sancheong: SC; Yangyang: YG). Thinning intensities for intermediate (I) and heavy (H) treatments are calculated based on the ratio of basal area of thinned trees to that of standing trees before thinning. DBH, SWC, total N, C/N ratio, and CEC represent diameter at breast height, soil gravimetric water content, total soil nitrogen concentration, soil carbon/nitrogen ratio, and cation exchange capacity, respectively.

\begin{tabular}{|c|c|c|c|c|c|c|c|c|c|c|c|c|c|c|c|c|}
\hline \multirow[t]{2}{*}{$\begin{array}{l}\text { Stand } \\
\text { type }\end{array}$} & \multirow[t]{2}{*}{$\begin{array}{l}\text { Study } \\
\text { stand }\end{array}$} & \multirow{2}{*}{ 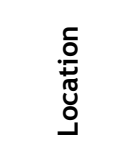 } & \multirow{2}{*}{ 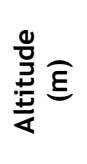 } & \multirow{2}{*}{$\begin{array}{l}\text { O } \\
0 \\
\frac{0}{n}\end{array}$} & \multirow{2}{*}{ 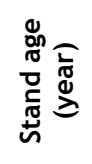 } & \multirow{2}{*}{$\begin{array}{l}\text { E્ } \\
\text { I } \\
\text { Iิ }\end{array}$} & \multirow{2}{*}{ 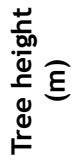 } & \multirow{2}{*}{ 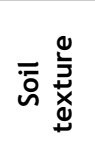 } & \multirow{2}{*}{ 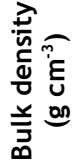 } & \multirow{2}{*}{ 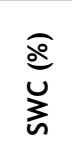 } & \multirow[t]{2}{*}{ 좀 } & \multirow{2}{*}{$\begin{array}{l}\widehat{\varrho} \\
z \\
\frac{\pi}{0} \\
\stackrel{0}{0}\end{array}$} & \multirow{2}{*}{$\begin{array}{l}\stackrel{0}{+0} \\
\substack{0 \\
z} \\
\text { U. }\end{array}$} & \multirow{2}{*}{ 岂 } & \multicolumn{2}{|c|}{$\begin{array}{l}\text { Thinning } \\
\text { intensity } \\
\text { (\%) }\end{array}$} \\
\hline & & & & & & & & & & & & & & & 1 & H \\
\hline \multirow[t]{4}{*}{ Larch } & GN & $\begin{array}{r}37^{\circ} 44^{\prime} \mathrm{N} \\
127^{\circ} 10^{\prime} \mathrm{E}\end{array}$ & 140 & 18 & $51-60$ & 27 & 25 & $\begin{array}{l}\text { Sandy } \\
\text { loam }\end{array}$ & 0.82 & 20.6 & 4.52 & 0.04 & 30.8 & 10.7 & 23 & 30 \\
\hline & IJ & $\begin{array}{r}38^{\circ} 10^{\prime} \mathrm{N} \\
128^{\circ} 15^{\prime} \mathrm{E}\end{array}$ & 430 & 32 & $41-50$ & 23 & 19 & $\begin{array}{l}\text { Sandy } \\
\text { loam }\end{array}$ & 0.68 & 13.7 & 5.20 & 0.04 & 28.5 & 10.0 & 17 & 44 \\
\hline & MF & $\begin{array}{r}35^{\circ} 52^{\prime} \mathrm{N} \\
127^{\circ} 50^{\prime} \mathrm{E}\end{array}$ & 910 & 21 & $51-60$ & 31 & 20 & $\begin{array}{l}\text { Loamy } \\
\text { sand }\end{array}$ & 0.64 & 29.0 & 4.80 & 0.18 & 32.0 & 16.2 & 21 & 32 \\
\hline & MS & $\begin{array}{r}35^{\circ} 52^{\prime} \mathrm{N} \\
127^{\circ} 49^{\prime} \mathrm{E}\end{array}$ & 930 & 15 & $51-60$ & 35 & 22 & $\begin{array}{l}\text { Loamy } \\
\text { sand }\end{array}$ & 0.60 & 32.3 & 4.61 & 0.37 & 15.4 & 16.9 & 24 & 33 \\
\hline \multirow[t]{4}{*}{ Oak } & $\mathrm{HA}$ & $\begin{array}{r}35^{\circ} 43^{\prime} \mathrm{N} \\
127^{\circ} 44^{\prime} \mathrm{E}\end{array}$ & 860 & 22 & $31-50$ & 21 & 15 & Loam & 0.72 & 34.0 & 4.29 & 0.41 & 16.3 & 10.4 & 15 & 30 \\
\hline & HS & $\begin{array}{r}37^{\circ} 29^{\prime} \mathrm{N} \\
127^{\circ} 49^{\prime} \mathrm{E}\end{array}$ & 340 & 31 & $41-50$ & 18 & 14 & $\begin{array}{l}\text { Sandy } \\
\text { loam }\end{array}$ & 0.78 & 23.0 & 4.78 & 0.08 & 22.5 & 9.8 & 22 & 35 \\
\hline & SC & $\begin{array}{r}35^{\circ} 22^{\prime} \mathrm{N} \\
127^{\circ} 51^{\prime} \mathrm{E}\end{array}$ & 480 & 22 & $31-50$ & 24 & 15 & Loam & 0.81 & 36.6 & 4.27 & 0.50 & 10.7 & 10.4 & 15 & 30 \\
\hline & YG & $\begin{array}{r}37^{\circ} 58^{\prime} \mathrm{N} \\
128^{\circ} 42^{\prime} \mathrm{E}\end{array}$ & 270 & 21 & $41-50$ & 22 & 15 & $\begin{array}{l}\text { Sandy } \\
\text { loam }\end{array}$ & 0.83 & 25.5 & 5.43 & 0.08 & 25.4 & 13.9 & 17 & 35 \\
\hline
\end{tabular}


by dividing the dry mass of the mineral soil samples $(<2 \mathrm{~mm})$ at $105^{\circ} \mathrm{C}$ into the volume of the corer $\left(406.94 \mathrm{~cm}^{3}\right.$ - Noh et al. 2010 , Kim et al. 2015C). The dry mass of the CWD in the sub-subplots was estimated by multiplying the wet mass of the CWD in the subsubplots with the dry mass to wet mass ratio of the CWD samples (Korea Forest Research Institute 2010). The $C$ concentration of the forest floor, mineral soil, and CWD samples was analyzed using an elemental analyzer (vario Macro, Elementar Analysensysteme $\mathrm{GmbH}$, Germany). The $\mathrm{C}$ storages on the forest floor and in CWD were determined based on the dry mass and the $C$ concentration, and that in the mineral soil was calculated based on the soil bulk density, depth, and C concentration.

\section{Data analysis}

The differences in $C$ storages between the thinned and the control plots were standardized by estimating the ES based on Hedges' $d$. For the ES estimation, each study stand was treated as a case study with two thinning treatments $(\mathrm{I}$ and $\mathrm{H})$ and a control, and the subplot was used as the unit of replication for each treatment $(n=$ 3). The mineral soil $\mathrm{C}$ storages at depths of $0-10,10-20$, and $20-30 \mathrm{~cm}$ in a sampling point were summed before the statistical analysis to estimate total mineral soil $C$ storage at $0-30 \mathrm{~cm}$. The ES for mineral soil $C$ storage was determined using the mineral soil C storage at $0-30 \mathrm{~cm}$.

The ES for individual treatments was quantified as follows (Nakagawa \& Cuthill
2007 - eqn. 1):

$$
E S=\frac{\bar{x}_{t}-\bar{x}_{c}}{S_{\text {pooled }}} \cdot\left[1-\frac{3}{4\left(n_{t}+n_{c}-2\right)-1}\right]
$$

where $\bar{x}_{\mathrm{t}}$ is the $\mathrm{C}$ storage $\left(\mathrm{Mg} \mathrm{C} \mathrm{ha} \mathrm{a}^{-1}\right)$ of a thinned plot within a study stand, $\bar{x}_{\mathrm{c}}$ is the C storage (Mg C ha-1) of a control plot within a study stand, $n_{\mathrm{t}}$ is the number of replications for the thinned plot, $n_{\mathrm{c}}$ is the number of replications for the control plot, and $s_{\text {pooled }}$ is the pooled standard deviation, which was calculated as following (Nakagawa \& Cuthill 2007 - eqn. 2):

$$
s_{\text {pooled }}=\sqrt{\frac{\left(n_{t}-1\right) s_{t}^{2}+\left(n_{c}-1\right) s_{c}^{2}}{n_{t}+n_{c}-2}}
$$

where $s_{\mathrm{t}}$ is the standard deviation for the thinned plot and $s_{\mathrm{c}}$ is the standard deviation for the control plot. The 95\% confidence interval $(\mathrm{Cl})$ for the ES was estimated as following (Nakagawa \& Cuthill 2007 - eqn. 3):

$$
95 \% C I=E S \pm 1.96 \sqrt{\frac{n_{t}+n_{c}}{n_{t} \cdot n_{c}}+\frac{E S^{2}}{2\left(n_{t}+n_{c}-2\right)}}
$$

The estimated ESs were sorted according to stand type (larch or oak) and were summarized by constructing the cumulative ES for each stand type. The cumulative ESs were determined using a random-effect model which assumed that variation across individual ESs originated from both observation error and true unmeasured differences among studies (Rosenberg et al.
2000). A two-tailed $t$ distribution was utilized for the quantification of the $95 \% \mathrm{Cl}$ of the cumulative ES. Detailed equations for summarizing ESs are presented in Rosenberg et al. (2000). An ES was indicated as significant when its $95 \% \mathrm{Cl}$ did not overlap the zero value.

ESs based on Hedges' $d$ can show standardized differences in the $C$ storages of thinned and control plots. An ES above zero implies that a thinned plot (I or $\mathrm{H}$ treatment) has higher $\mathrm{C}$ storage than a control plot, whereas that below zero means that a thinned plot has lower $C$ storage. Cumulative ESs in the present study are summaries of the ESs for the larch and the oak stands. $95 \% \mathrm{Cl}$ and statistical significance of ESs or cumulative ESs can be used to determine whether ES or cumulative ES significantly differs from zero (where zero represents no thinning effect).

\section{Results}

The average forest floor C storage of the thinned plots was $0.48 \mathrm{Mg} \mathrm{C}$ ha-1 higher than that of the control plots in the larch stands, but $0.16 \mathrm{Mg} \mathrm{C}^{-1}$ lower than that of the control plots in the oak stands (Fig. 1a). These differences corresponded to approximately 6\% (larch) and 3\% (oak) of the mean forest floor $C$ storage for the control treatments. None of the ESs for forest floor C storage were significant in either the larch or oak stands (Tab. 2). The cumulative ES for forest floor C storage was non-significant for both the larch and oak stands (Tab. 3).
Fig. 1 - Summary of forest floor carbon (C) storage (a), mineral soil $C$ storage at a depth of $0-30 \mathrm{~cm}$ (b), coarse woody debris $\mathrm{C}$ storage (c), and total C storage of dead organic matter

(d) of the thinned (intermediate: I; heavy: $\mathrm{H}$ ) and control plots in

the larch and oak stands. Vertical and horizontal bars represent the standard errors for the thinned and control plots, respectively.
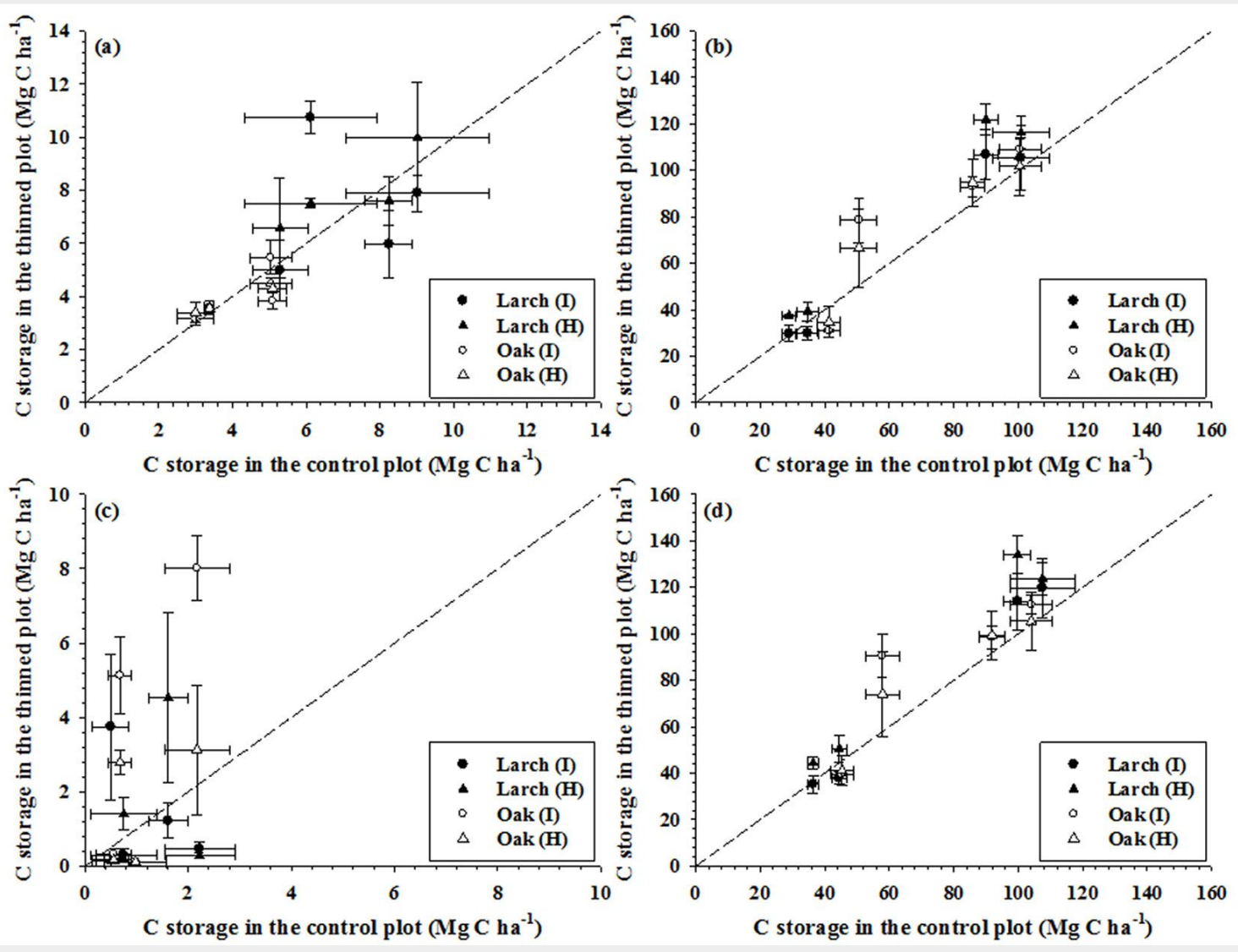
Tab. 2 - The effect size of intermediate $(\mathrm{I})$ and heavy $(\mathrm{H})$ thinning treatments on carbon storage on forest floor, in mineral soil, in coarse woody debris (CWD), and in dead organic matter for the larch (Gwangneung: GN; Inje: IJ; Muju 1: MF; Muju 2: MS) and oak stands (Hamyang: HA; Hoengseong: HS; Sancheong: SC; Yangyang: YG). The values in the table represent the effect sizes, followed by the $95 \%$ confidence interval. Values with an asterisk denote significant effect sizes.

\begin{tabular}{|c|c|c|c|c|c|c|c|c|}
\hline \multirow{2}{*}{$\begin{array}{l}\text { Study } \\
\text { stand }\end{array}$} & \multicolumn{2}{|c|}{ Forest floor } & \multicolumn{2}{|c|}{ Mineral soil } & \multicolumn{2}{|c|}{ CWD } & \multicolumn{2}{|c|}{ Dead organic matter } \\
\hline & I & $\mathrm{H}$ & 1 & $\mathrm{H}$ & 1 & $\mathrm{H}$ & 1 & $\mathrm{H}$ \\
\hline GN & $-0.3 \pm 1.6$ & $0.2 \pm 1.6$ & $-0.7 \pm 1.7$ & $0.5 \pm 1.6$ & $-0.4 \pm 1.6$ & $0.5 \pm 1.6$ & $-1.3 \pm 1.8$ & $0.5 \pm 1.6$ \\
\hline IJ & $-0.1 \pm 1.6$ & $0.4 \pm 1.6$ & $0.1 \pm 1.6$ & $2.6 \pm 2.4^{*}$ & $-1.6 \pm 1.9$ & $-1.8 \pm 2.0$ & $-0.0 \pm 1.6$ & $1.8 \pm 2.0$ \\
\hline MF & $-1.0 \pm 1.7$ & $-0.3 \pm 1.6$ & $0.9 \pm 1.7$ & $2.7 \pm 2.4^{*}$ & $-0.4 \pm 1.6$ & $0.8 \pm 1.7$ & $0.7 \pm 1.6$ & $2.6 \pm 2.4^{*}$ \\
\hline MS & $1.5 \pm 1.9$ & $0.5 \pm 1.6$ & $0.1 \pm 1.6$ & $1.8 \pm 1.7$ & $1.0 \pm 1.7$ & $-0.6 \pm 1.5$ & $0.3 \pm 1.6$ & $0.9 \pm 1.7$ \\
\hline $\mathrm{HA}$ & $0.1 \pm 1.7$ & $0.4 \pm 1.7$ & $0.7 \pm 1.7$ & $0.0 \pm 1.7$ & $-0.4 \pm 1.7$ & $-0.7 \pm 1.7$ & $0.7 \pm 1.7$ & $0.0 \pm 1.7$ \\
\hline HS & $0.4 \pm 1.6$ & $0.5 \pm 1.6$ & $-1.8 \pm 2.0$ & $-0.5 \pm 1.6$ & $2.7 \pm 2.5^{*}$ & $3.4 \pm 2.8^{*}$ & $-1.7 \pm 2.0$ & $-0.5 \pm 1.6$ \\
\hline SC & $0.3 \pm 1.7$ & $-0.6 \pm 1.7$ & $0.7 \pm 1.7$ & $0.5 \pm 1.7$ & $-0.9 \pm 1.8$ & $-0.9 \pm 1.8$ & $0.6 \pm 1.7$ & $0.4 \pm 1.7$ \\
\hline YG & $-1.7 \pm 1.9$ & $-1.2 \pm 1.8$ & $1.6 \pm 1.9$ & $0.5 \pm 1.6$ & $3.5 \pm 2.9^{*}$ & $0.3 \pm 1.6$ & $1.5 \pm 1.9$ & $0.5 \pm 1.6$ \\
\hline
\end{tabular}

On average, the mineral soil $C$ storage at $0-30 \mathrm{~cm}$ depth of the thinned plots was 9.64 Mg C ha-1 (larch) and 6.55 Mg C ha(oak) higher than those of the control plots (Fig. 1b), a difference of $15 \%$ and $9 \%$ for the larch and oak stands, respectively. The ES for mineral soil C storage was significant for the $\mathrm{H}$ treatment plot in the larch forests at the IJ and MF stands (Tab. 2). The average mineral soil $\mathrm{C}$ storage in the $\mathrm{H}$ treatment plot at these larch stands was $32 \%$ higher than that in the control plots. In contrast, none of the ESs for mineral soil C storage were significant in the oak stands (Tab. 2). The cumulative ES for mineral soil $C$ storage was non-significant for both stand types (Tab. 3)

The mean CWD C storage of the thinned plots was $0.24 \mathrm{Mg} \mathrm{C}^{-1}$ (larch) and $1.37 \mathrm{Mg}$ $\mathrm{C}$ ha $^{-1}$ (oak) higher than those of the control plots (Fig. 1C), corresponding to differences of $18 \%$ and $125 \%$ for the larch and oak stands, respectively. The ES for CWD C storage in the oak stands was significant for the stands HS and YG (Tab. 2). The mean CWD C storage at these oak stands was $234 \%$ higher in the thinned plots than in the control plots. However, the ES for CWD C storage was non-significant for all treatment plots within the larch stands (Tab. 2). The cumulative ES for CWD C storage was non-significant for both stand types (Tab. 3).

Total C storage of dead organic matter (i.e., the sum of the forest floor, mineral soil, and CWD C storages) was averaged as 82.45 Mg C ha ${ }^{-1}$ and $72.07 \mathrm{Mg} \mathrm{C}^{-1}$ in the thinned and control plots of the larch stands and $82.56 \mathrm{Mg} \mathrm{C} \mathrm{ha-1}$ and $74.79 \mathrm{Mg} \mathrm{C}$ ha $^{-1}$ in those of the oak stands, respectively (Fig. 1d). The average $C$ storage of dead organic matter in the thinned plots was

Tab. 3 - The cumulative effect size for carbon storage on forest floor, in mineral soil, in coarse woody debris (CWD), and in dead organic matter for the larch and oak stands. The values represent cumulative effect sizes followed by the $95 \%$ confidence interval.

\begin{tabular}{lcccc}
\hline Stand type & $\begin{array}{c}\text { Forest } \\
\text { floor }\end{array}$ & $\begin{array}{c}\text { Mineral } \\
\text { soil }\end{array}$ & CWD & $\begin{array}{c}\text { Dead organic } \\
\text { matter }\end{array}$ \\
\hline Larch & $0.0 \pm 0.5$ & $0.6 \pm 0.8$ & $-0.2 \pm 0.8$ & $0.5 \pm 0.8$ \\
Oak & $-0.1 \pm 0.6$ & $0.2 \pm 0.7$ & $0.5 \pm 1.3$ & $0.2 \pm 0.7$ \\
\hline
\end{tabular}

thinning could reduce litter production from the overstory (Kim et al. 2009). Thinning could also alter soil temperature and moisture conditions by allowing greater light penetration through the canopy and reducing stand-scale transpiration (Gebhardt et al. 2014, Masyagina et al. 2006). These changes in soil microclimate after thinning could accelerate litter decomposition and consequently decrease forest floor $\mathrm{C}$ storage (Inagaki et al. 2011, Mu et al. 2013). However, thinning may also increase forest floor C storage in the short term. Thinning with the stem-only harvesting introduces a significant volume of leaves and twigs to the forest floor as thinning residues (Hytönen \& Moilanen 2014). The increase in light availability following thinning could also promote litter production from understory vegetation (Son et al. 2004). Thus, it can be speculated that the non-significant effect of thinning on the forest floor $C$ storage in the present study may be due to the fact that the influences of thinning cancel each other out, at least in the short term.

Thinning can alter mineral soil $C$ storage by increasing root mortality, incorporating thinning residues, and changing litter production and heterotrophic soil respiration (Hwang \& Son 2006, Ko et al. 2014, Schilling et al. 1999). Even though two larch stands exhibited significant increases in mineral soil C storage three years after thinning, it was found that these significant increases were not common in the present study as the impact of thinning on mineral soil C storage was minimal in other study stands. These results demonstrate that three years might not be long enough for consistently significant changes in mineral soil C storage to become apparent after thinning within the study stands. Our findings agree with those obtained from other studies on multiple study sites. A field study by Boerner et al. (2008) observed that the influence of thinning on mineral soil $C$ storage tended to be marginal across study sites after 2-4 years, but one study site exhibited a significant increase in mineral soil $C$ storage due to thinning. Inagaki et al. (2011) reported that thinning did not significantly affect mineral soil C storage in any forests under various climatic conditions 
after 1-3 years. Powers et al. (2012) showed that there was no significant difference in mineral soil $C$ storage between thinned and un-thinned forests across a chronosequence.

The effects of thinning on mineral soil $C$ storage are expected to differ between needle-leaved and broad-leaved forests (Johnson \& Curtis 2001, Nave et al. 2010). In the present study, the heavy thinning treatments significantly influenced mineral soil $C$ storage within the larch forests at two study stands, but these trends were not found within any of the oak stands. Similarly, an extensive meta-analysis by Johnson \& Curtis (2001) showed that the stem-only harvesting increased mineral soil C storage of needle-leaved forests, but had non-significant effect in broad-leaved forests. In contrast to these findings, Jurgensen et al. (2012) demonstrated that thinning decreased $C$ storage in the mineral $A$ horizon in a pine forest, while this tendency was not observed in a broad-leaved forest. The mechanisms behind these differences in the effects of thinning between needle-leaved and broad-leaved forests remain unclear. However, initial shifts of mineral soil $C$ in thinned needle-leaved forests are often attributed to the significant input of organic matter from dead roots, leaves, and slashes of thinned trees (Hwang \& Son 2006, Mu et al. 2013, Ko et al. 2014). Thus, differences in mineral soil $C$ patterns due to thinning might result from differences in the decomposition rate of incorporated organic matters, because quality and recalcitrant constituents of organic matter vary between species (Silver \& Miya 2001). The different soil C patterns due to thinning could also be attributed to differences in soil conditions and enzymatic activities between stand types (Cheng et al. 2013, Rey et al. 2008), because these factors play an important role in soil $\mathrm{C} \mathrm{mi-}$ neralization.

In the present study, the effects of thinning on CWD C storage were inconsistent within the larch and oak stands three years following thinning. Our results were similar to those of Boerner et al. (2008) who reported no consistent and significant impact of thinning on CWD C storage after 2-4 years. Despite lack of significance shown by the cumulative effect sizes for CWD C storage, significant increases in CWD C storage were observed in the oak forests at two study stands. Similarly, previous research in an oak forest in central Korea observed $105-165 \%$ higher CWD mass within thinned plots compared to that within control plots three years after thinning (Kim et al. 2015C). These significant differences in CWD $C$ storage due to thinning could be the result of the unharvested logs in these forests, because the amount of CWD in a recently thinned forest is related to the strategy used to harvest thinning residues (Hytönen \& Moilanen 2014). Although some studies suggested that thinning could reduce CWD C storage by controlling competitions among remaining trees in the long term (Powers et al. 2012, Ruiz-Peinado et al. 2013), it was not found in the present study because of the short study period.

As thinning with the stem-only harvesting can promote the incorporation of thinning residues into dead organic matter $C$ pools (Hytönen \& Moilanen 2014, Ko et al. 2014), we expected increases in the $C$ storage of dead organic matter following thinning. Nevertheless, the obtained results imply that the applied thinning treatments did not consistently increase the $C$ storage of dead organic matter within the study stands at least after three years. Although a significant increase in the C storage of dead organic matter was found at one larch stand, it appeared to be uncommon and idiosyncratic, since other study stands did not exhibit any significant changes in the $C$ storage. These tendencies might result from non-significant shifts of mineral soil $C$ storage shown at most of the individual study stands. Because these non-significances might be the results of the short study period, further studies should focus on the long term soil $C$ budget in order to ascertain whether the impact of thinning on the $C$ storage of dead organic matter will remain non-significant or not.

\section{Conclusion}

ES estimation in the present study found significant ESs for mineral soil C storage in a few larch stands and for CWD C storage in a few oak stands; however, cumulative ES was non-significant in either stand type. These results demonstrate that the applied thinning treatments had no consistently significant influence on the $C$ storage of dead organic matter within the larch and oak stands after three years, although thinning may affect the $C$ storage in two stand types differently. The results of the present study may be inconclusive because three years may be too short to result in any substantial changes in the $C$ storage across the study stands over this period. Therefore, further studies will be necessary to clearly interpret the patterns in the larch and oak stands and to ascertain whether the applied thinning treatments impact the $C$ storage of dead organic matter in the long term. Nonetheless, we expect that the present study will contribute to an understanding of the impacts of thinning on the C storage of dead organic matter in multiple study stands as summarized by ES estimation.

\section{Acknowledgements}

This study was supported by the Korean National Institute of Forest Science (FMo1 01-2009-01) and the Korean Ministry of Environment (2014001310008, 20140018100 02). We appreciate the assistance we received in the field and laboratory from undergraduate and graduate students in the Ecosystem Ecology Laboratory of Korea University and the Forest Soil Laboratory of Gyeongnam, National University of
Science and Technology. We would like to thank the foresters and the managers of the study stands for their cooperation.

\section{References}

Boerner REJ, Huang J, Hart SC (2008). Fire, thinning, and the carbon economy: effects of fire and fire surrogate treatments on estimated carbon storage and sequestration rate. Forest Ecology and Management 255: 3081-3097. - doi: 10.1016/j.foreco.2007.11.021

Byun JG, Lee WK, Kim M, Kwak DA, Kwak H, Park T, Byun WH, Son Y, Choi JK, Lee YJ, Saborowski J, Chung DJ, Jung JH (2013). Radial growth response of Pinus densiflora and Quercus spp. to topographic and climatic factors in South Korea. Journal of Plant Ecology 6: 380-392. doi: 10.1093/jpe/rttoo1

Cheng F, Peng X, Zhao P, Yuan J, Zhong C, Cheng Y, Cui C, Zhang S (2013). Soil microbial biomass, basal respiration and enzyme activity of main forest types in the Qinling Mountains. PloS One 8: e67353. - doi: 10.1371/journal.pone.0067353

Cheng XR, Yu MK, Zhang CX, Wang W (2012). Carbon density and its spatial distribution in Quercus acutissima plantations under different thinning intensities. Chinese Journal of Applied Ecology 24: 1175-1180. [in Chinese with English abstract]

Gebhardt T, Häberle K-H, Matyssek R, Schulz C, Ammer C (2014). The more, the better? Water relations of Norway spruce stands after progressive thinning. Agricultural and Forest Meteorology 197: 235-243. - doi: 10.1016/j.agrfor met.2014.05.013

Gurevitch J, Hedges LV (1999). Statistical issues in ecological meta-analyses. Ecology 80: 11421149. - doi: 10.2307/177061

Hwang J, Son Y (2006). Short-term effects of thinning and liming on forest soils of pitch pine and Japanese larch plantations in central Korea. Ecological Research 21: 671-680. - doi: 10.1007/s11284-006-0170-1

Hytönen J, Moilanen M (2014). Effect of harvesting method on the amount of logging residues in the thinning of Scots pine stands. Biomass and Bioenergy 67: 347-353. - doi: 10.1016/j. biombioe.2014.05.004

Inagaki Y, Nakanishi A, Fukata H (2011). Soil properties and nitrogen utilization of hinoki cypress as affected by strong thinning under different climatic conditions in the Shikoku and Kinki districts in Japan. Journal of Forest Research 16: 405-413. - doi: 10.1007/s10310-011-02 71-8

Jandl R, Lindner M, Vesterdal L, Bauwens B, Baritz R, Hagedorn F, Johnson DW, Minkkinen K, Byrne KA (2007). How strongly can forest management influence soil carbon sequestration? Geoderma 137: 253-268. - doi: 10.1016/j.geoder ma.2006.09.003

Johnson DW, Curtis PS (2001). Effects of forest management on soil $\mathrm{C}$ and $\mathrm{N}$ storage: meta analysis. Forest Ecology and Management 140: 227-238. - doi: 10.1016/s0378-1127(00)00282-6 Jurgensen MF, Tarpey R, Pickens J, Kolka R, Palik $B$ (2012). Long-term effect of silvicultural thinnings on soil carbon and nitrogen pools. Soil Science Society of America Journal 76: 14181425. - doi: 10.2136/sssaj2011.0257

Khaine I, Woo SY (2015). An overview of interre- 
lationship between climate change and forests. Forest Science and Technology 11: 11-18. - doi: 10.1080/21580103.2014.932718

Kim C, Son Y, Lee W-K, Jeong J, Noh N-J (2009). Influences of forest tending works on carbon distribution and cycling in a Pinus densiflora S. et Z. stand in Korea. Forest Ecology and Management 257: 1420-1426. - doi: 10.1016/j.foreco.20 08.12.015

Kim H, Kim Y-H, Kim R, Park H (2015a). Reviews of forest carbon dynamics models that use empirical yield curves: CBM-CFS3, CO2FIX, CASMOFOR, EFISCEN. Forest Science and Technology. - doi: 10.1080/21580103.2014.987325

Kim M, Lee W-K, Kim Y-S, Lim C-H, Song C, Park $\mathrm{T}$, Son $\mathrm{Y}$, Son $\mathrm{Y}-\mathrm{M}$ (2015b). Impact of thinning intensity on the diameter and height growth of Larix kaempferi stands in central Korea. Forest Science and Technology. - doi: 10.1080/21580 103.2015.1075435

Kim S, Yoon TK, Han S, Han SH, Lee J, Kim C, Lee S-T, Seo KW, Yang A-R, Son Y (2015C). Initial effects of thinning on soil carbon storage and base cations in a naturally regenerated Quercus spp. forest in Hongcheon, Korea. Forest Science and Technology 11: 172-176. - doi: 10.1080/ 21580103.2014.957357

Ko S, Yoon TK, Kim S, Kim C, Lee S-T, Seo KW, Son $Y$ (2014). Thinning intensity effects on carbon storage of soil, forest floor and coarse woody debris in Pinus densiflora stands. Journal of Korean Forest Society 103: 30-36. [in Korean with English abstract] - doi: 10.14578/ jkfs.2014.103.1.30-doi:10.14578/jkfs.2014.103.1.30 Kwak D-A, Lee W-K, Son Y, Choi S, Yoo S, Chung DJ, Lee S-H, Kim SH, Choi JK, Lee YJ, Byun W-H (2012). Predicting distributional change of forest cover and volume in future climate of South Korea. Forest Science and Technology 8: 105-115. - doi: 10.1080/21580103.2012.673751 Korea Forest Research Institute (2010). Survey manual for biomass and soil carbon. Korea For- est Research Institute, Seoul, South Korea, pp. 60.

Lal R (2005). Forest soils and carbon sequestration. Forest Ecology and Management 220 (1-3): 242-258. - doi: 10.1016/j.foreco.2005.08.015

Lee SK, Son Y, Lee WK, Yang A-R, Noh NJ, Byun $J-G$ (2010). Influence of thinning on carbon storage in a Japanese larch (Larix kaempferi) plantation in Yangpyeong, central Korea. Forest Science and Technology 6: 35-40. - doi: 10.1080/ 21580103.2010.9656356

Masyagina OV, Hirano T, Ji DH, Choi DS, Qu L, Fujinuma Y, Sasa K, Matsuura Y, Prokushkin SG, Koike T (2006). Effect of spatial variation of soil respiration rates following disturbance by timber harvesting in a larch plantation in northern Japan. Forest Science and Technology 2: 80-91. - doi: 10.1080/21580103.2006.9656303

Mu C, Lu H, Wang B, Bao X, Cui W (2013). Shortterm effects of harvesting on carbon storage of boreal Larix gmelinii-Carex schmidtii forested wetland in Daxing'anling, northeast China. Forest Ecology and Management 293: 140-148. doi: 10.1016/j.foreco.2012.12.031

Nakagawa S, Cuthill IC (2007). Effect size, confidence interval and statistical significance: a practical guide for biologists. Biological Reviews 82: 591-605. - doi: 10.1111/j.1469-185X.200 7.00027.x

Nave LE, Vance ED, Swanston CW, Curtis PS (2010). Harvest impacts on soil carbon storage in temperate forests. Forest Ecology and Management 259: 857-866. - doi: 10.1016/j.foreco. 2009.12.009

Noh N-J, Son Y, Lee S-K, Seo K-W, Heo S-J, Yi M-J, Park P-S, Kim R-H, Son Y-M, Lee K-H (2010). Carbon and nitrogen storage in an age-sequence of Pinus densiflora stands in Korea. Science China Life Sciences 53: 822-830. - doi: 10.1007/s114 27-010-4018-0

Powers MD, Kolka RK, Bradford JB, Palik BJ, Fraver S, Jurgensen MF (2012). Carbon stocks across a chronosequence of thinned and unmanaged red pine (Pinus resinosa) stands. Ecological Applications 22: 1297-1307. - doi: 10.1890/ 11-0411.1

Rey A, Pegoraro E, Jarvis PG (2008). Carbon mineralization rates at different soil depths across a network of European forest sites (FORCAST). European Journal of Soil Science 59: 1049-1062. - doi: 10.1111/j.1365-2389.2008.010 $65 . x$

Rosenberg MS, Adams DC, Gurevitch J (2000). MetaWin: statistical software for meta-analysis, version 2.0. Sinauer, Sunderland, MA, USA, pp. 128. [online] URL: http://library.wur.nI/WebQue $\mathrm{ry} / \mathrm{clc} / 1730075$

Ruiz-Peinado R, Bravo-Oviedo A, López-Senespleda E, Montero G, Río M (2013). Do thinning influence biomass and soil carbon stocks in Mediterranean maritime pinewoods? European Journal of Forest Research 132: 253-262. - doi: 10.1007/s10342-012-0672-z

Schilling EB, Lockaby BG, Rummer R (1999). Belowground nutrient dynamics following tree harvest intensities on the Pearl River floodplain, Mississippi. Soil Science Society of America Journal 63: 1856-1868. - doi: 10.2136/sssaj19 $99.6361856 x$

Silver WL, Miya RK (2001). Global patterns in root decomposition: comparisons of climate and litter quality effects. Oecologia 129: 407419. - doi: 10.1007/s004420100740

Son Y, Lee YY, Jun YC, Kim Z-S (2004). Light availability and understory vegetation four years after thinning in a Larix leptolepis plantation of central Korea. Journal of Forest Research 9: 133-139. - doi: 10.1007/s10310-003-0071-x

Zhou D, Zhao SQ, Liu S, Oeding J (2013). A metaanalysis on the impacts of partial cutting on forest structure and carbon storage. Biogeosciences 10: 3691-3703. - doi: 10.5194/bg-10-36 91-2013 